\title{
PENGARUH LINGKUNGAN KERJA, BEBAN KERJA DAN KONFLIK KERJA TERHADAP STRES KERJA KARYAWAN PT. INTI MANUNGGAL SEJAHTERA ABADI
}

\author{
Thea Herawati Rahardjo*, Choirun Nissa Nurdiyanti \\ *) Dosen Fakultas Ekonomi Jurusan Manajemen Universitas Tarumanagara \\ Thearahardjo@gmail.com; choirunnisa.nd@gmail.com
}

\begin{abstract}
To overcome the level of job stress employees need to consider several factors including work environment, workload and work conflict. This study aims to determine the effect of work environment, workload and work conflict simultaneously or partially to the employee work stress of PT. Inti Manunggal Sejahtera Abadi.

The research sample are 44 production employees'. The multiple linear regression, $t$ test and $F$ test are used as the analysis techniques. The results showed that work environment, workload and work conflict simultaneously have a significant effect on employee's job stress. While $t$ test results indicate that workload and work conflict partially affect the employee's work stress, while the work environment has no effect.
\end{abstract}

Keywords: job environment, workload, job conflict, job stress.

\section{PENDAHULUAN \\ Latar Belakang}

Lingkungan bisnis dewasa ini yang tumbuh dan berkembang dengan sangat dinamis, sangat memerlukan adanya sistem manajemen yang efektif dan efisien artinya dapat dengan mudah berubah atau menyesuaikan diri dan dapat mengakomodasikan setiap perubahan secara cepat, tepat dan terarah serta biaya yang murah. Kemampuan sumber daya manusia sebagai asset (human capital) diperlukan dalam rangka mencapai tujuan organisasi. Namun di sisi lain ketidak mampuan perusahaan dalam mengelola sumber daya manusia akan mengakibatkan dampak bagi tidak tercapainya tujuan perusahaan.

Manajemen sumberdaya berperan pentingnya dalam mengendalikan dan mengelola persoalan yang dihadapi pada pekerja di dalam internal organisasi dapat memberikan efek pada terciptanya tata kelola organisasi yang efektif dan efisien. Masalah yang sering dihadapi oleh para karyawan dapat di sebabkan oleh berbagai faktor misalnya factor kepemimpinan, hubungan pribadi, kejelasan peran, konflik kerja, psikologis pribadi, lingkungan dan lain lain. Dan beberapa faktor tersebut dapat menyebabkan stress kerja sehingga memicu kinerja yang kurang optimal di perusahaan. Lazarus dan Folkman (dalam Evanjeli, 2012) menjelaskan stres sebagai kondisi individu yang dipengaruhi oleh lingkungan. Kondisi stres di prusahaan dapat terjadi karena ketidakseimbangan antara tekanan yang dihadapi individu dan kemampuan untuk menghadapi tekanan tersebut atau juga karena factor eksternal lainnya.

Lingkungan kerja adalah kehidupan sosial, psikologi, dan fisik dalam perusahaan yang berpengaruh terhadap pekerja dalam melaksanakan tugasnya. Lingkungan kerja yang baik akan dapat mempunyai pengaruh terhadap kinerja pegawai adalah iklim organisasi atau lingkungan kerja dimana pegawai tersebut melaksanakan tugas dan tanggung jawabnya. Untuk mengoptimalkan produktivita karyawan harus tercipta iklim organisasi atau lingkungan yang kondusif sebagai prasyarat peningkatan kinerja pegawai secara maksimal. Adapun faktor-faktor yang mempengaruhi terciptanya iklim organisasi atau lingkungan kerja antara lain adanya kesempatan untuk promosi sesuai dengan prestasinya serta adanya suatu penghargaan dan kekompakkan dalam bekerja.

Faktor lain dapat menyebabkan stress kerja dapat disebabkan pula oleh beban kerja, karena beban kerja seseorang sudah ditentukan dalam bentuk standar kerja perusahaan menurut jenis pekerjaannya. Beban kerja karyawan dapat terjadi dalam tiga kondisi. Pertama, 
beban kerja sesuai standar. Kedua, beban kerja yang terlalu tinggi. Ketiga, beban kerja yang terlalu rendah. Beban kerja yang terlalu berat atau ringan akan berdampak terjadinya inefisiensi kerja. Pemberian kerja yang terlalu berlebihan terhadap karyawan dapat menimbulkan stress yang berkepanjangan, yaitu kondisi atau keadaan yang tidak menyenangkan yang dihadapi oleh setiap orang baik secara fisik maupun mental.

Selain lingkungan dan beban kerja, faktor lain yang menyebabkan stres kerja adalah konflik kerja. Menurut Malayu Hasibuan (2013:199), konflik adalah suatu persaingan kurang sehat berdasarkan ambisi dalam hal-hal seperti ketidakcocokan, ketidaksetujuan atau ketegangan baik intra individu maupun interentitas sosial seperti individu, kelompok ataupun organisasi.

Di Berdasarkan penelitian mengenai Stres Kerja Karyawan, A.A. Hatmawan (2015) menyatakan bahwa Lingkungan Kerja tidak berpengaruh terhadap Stres Kerja sedangkan variable konflik dan beban kerja berpengaruh positif dan signifikan terhadap Stres Kerja. Namun penelitian lain DM Pratiwi \& Ratri W (2015) (Studi kasus di PT. Krakatau Steel Tbk. Divisi CRM) mengemukakan bahwa Lingkungan Kerja berpengaruh terhadap Stres Kerja sedangkan variable konflik dan beban kerja berpengaruh positif dan signifikan terhadap Stres Kerja. Lingkungan kerja fisik dan non fisik dalam suatu perusahaan merupakan suatu kondisi pekerjaan untuk memberikan suasana dan situasi kerja karyawan yang nyaman dalam pencapaian tujuan yang diinginkan oleh suatu perusahaan. Kondisi kerja yang buruk berpotensi menjadi penyebab karyawan mudah mudah stres, sulit berkonsentrasi dan menurunnya produktivitas kerja.

Berdasarkan penjelasan diatas maka tertarik melakukan penelitian dengan judul Pengaruh Lingkungan Kerja, Beban Kerja serta Konflik Kerja terhadap Stres Kerja Karyawan PT. Inti Manunggal Sejahtera Abadi.

\section{LANDASAN TEORI Stres Kerja}

Menurut Handoko (2014:200) Stres kerja adalah suatu kondisi ketegangan yang mempengaruhi emosi, proses berpikir dan kondisi seseorang. Mangkunegara (2011:157) mendefinisikan stres kerja merupakan perasaan tertekan yang dialami karyawan dalam menghadapi pekerjaan. Stres kerja ini tampak dari sindrom, antara lain emosi tidak stabil, perasaan tidak tenang, suka menyendiri, sulit tidur, merokok yang berlebihan, tidak bisa rileks, cemas, tegang, gugup, tekanan darah meningkat dan mengalami gangguan pencernaan.

\section{Faktor dan Penyebab Timbulnya Stres}
a. Faktor-faktor Lingkungan
b. Faktor-faktor Organisasi
c. Faktor-faktor Pribadi

\section{Lingkungan Kerja}

Menurut Danang Sunyoto (2012:43) lingkungan kerja adalah segala sesuatu yang ada di sekitar para pekerja dan yang dapat memengaruhi dirinya dalam menjalankan tugas-tugas yang dibebankan, misalnya kebersihan, musik, penerangan dan lain-lain. Sedarmayanti (2011:1) mendefinisikan lingkungan kerja merupakan keseluruhan alat perkakas dan bahan yang dihadapi lingkungan sekitarnya di mana seseorang bekerja, metode kerjanya, serta pengaturan kerjanya baik sebagai perseorangan maupun sebagai kelompok. Menurut Mangkunegara (2011:105), menyatakan bahwa ada beberapa jenis lingkungan kerja, yaitu: 
a. Kondisi lingkungan kerja fisik yang meliputi faktor lingkungan tata ruang kerja dan faktor kebersihan dan kerapian ruang kerja.

b. Kondisi lingkungan kerja non fisik yang meliputi lingkungan sosial, status sosial, hubungan kerja dan sistem informasi.

c. Kondisi psikologis lingkungan kerja yang meliputi rasa bosan dan keletihan dalam bekerja

\section{Beban Kerja}

Menurut Tarwaka (2011:106) beban kerja adalah suatu yang muncul dari interaksi antara tuntutan tugas-tugas lingkungan kerja dimana digunakan sebagai tempat kerja, keterampilan dan persepsi dari pekerja. Munandar (2012:383) mendefnisikan beban kerja merupakan suatu kondisi dari pekerjaan dengan uraian tugasnya yang harus diselesaikan pada batas waktu tertentu. Faktor-faktor yang mempengaruhi beban kerja menurut L. Hadi Pranoto (2015:32) :

a. Faktor Ekstrnal yaitu Tugas yang meliputi keadaan tata ruang tempat kerja, kondisi ruang kerja, kondisi lingkungan kerja, sikap kerja, tanggung jawab, kompleksitas pekerjaan, emosi pekerjaan. Dan Organisasi kerja yang meliputi lamanya waktu kerja, waktu istirahat, shift kerja, sistem kerja dan sebagainya.Lingkungan kerja. Ini dapat memberikan beban tambahan yang meliputi, lingkungan kerja fisik, lingkungan kerja miniawi, lingkungan kerja biologis dan lingkungan kerja psikologis

b. Faktor Internal seperit faktor somatic (jenis kelamin, umur, ukuran tubuh, status gizi, kondisi kesehatan, dan sebagainya) dan faktor psikis (motivasi, persepsi, kepercayaan, keinginan, kepuasan dan sebagainya).

\section{Konflik Kerja}

Menurut Vetizhal Rivai (2011:999) dalam bukunya manajemen sumber daya manusia untuk perusahaan, konflik kerja adalah ketidaksesuaian antara dua atau lebih anggota-anggota atau kelompok (dalam suatu organisasi/perusahaan) yang harus membagi sumber daya yang terbatas atau kegiatan-kegiaan kerja dan atau karena kenyataan bahwa mereka mempunyai perbedaan status, tujuan, nilai, atau persepsi. Malayu Hasibuan (2010:199) juga mengemukakan bahwa konflik adalah persaingan yang kurang sehat berdasarkan ambisi dan sikap emosional dalam memperoleh kemenangan. Jenis konflik yang terjadi dalam lingkungan pekerjaan diantaranya menurut Veithzal Rivai (2011:1001) :
a. Konflik dalam diri seseorang
b. Konflik antar individu
c. Konflik antar-kelompok

\section{Kerangka Pemikiran}

Berdasarkan penjelasan diatas maka dapat dikembangkan kerangka pemikiran teoritis seperti dibawah ini

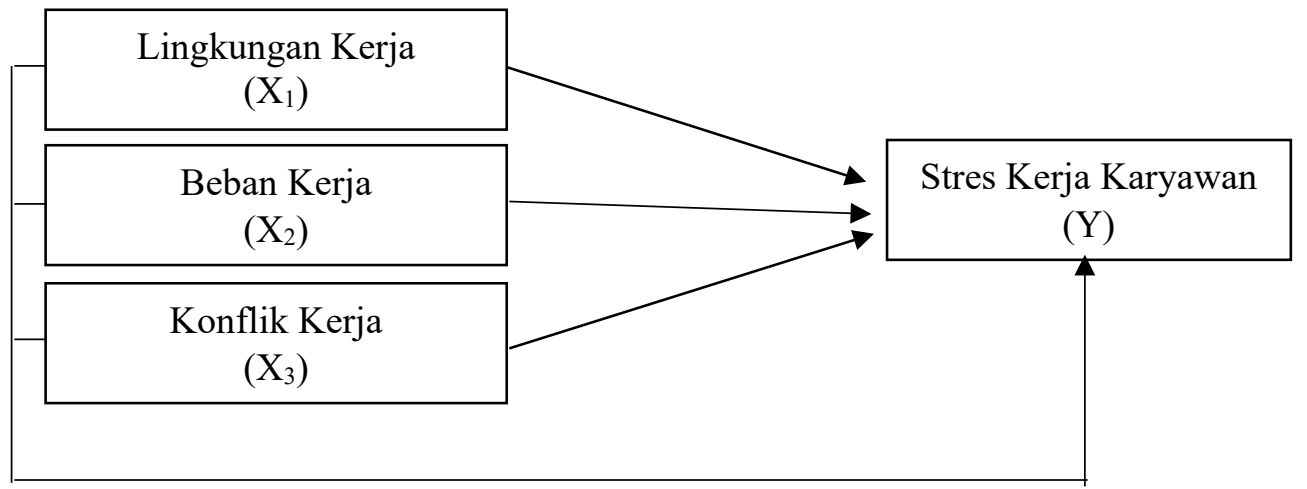




\section{Hipotesis}

Berdasarkan pembahasan di atas, maka hipotesis yang diajukan dalam penelitian ini adalah:

Ho = Diduga tidak ada pengaruh yang signifikan dari Variabel Lingkungan

Kerja, Beban Kerja dan Konflik Kerja terhadap Stres Kerja karyawan.

Ho = Diduga ada pengaruh yang signifikan dari Variabel Lingkungan Kerja, Beban Kerja dan Konflik Kerja terhadap Stres Kerja karyawan.

\section{METODE PENELITIAN}

\section{Desain Penelitian}

Penelitian ini menggunakan pendekatan kuantitatif dengan kategori penelitian asosiatif kausal merupakan penelitian yang bertujuan untuk membuktikan hubungan sebab akibat atau hubungan mempengaruhi dan dipengaruhi dari variabel-variabel yang diteliti. Penelitian kausalitas bertujuan untuk mengetahui pengaruh hubungan variabel dependen dan independen. Penelitian ini menerapkan metode survei dengan menggunakan instrumen berupa kuisioner yang terdiri darisejumlah pernyataan terstruktur dan dibagikan kepada responden, yakni para karyawan PT. Inti Manunggal Sejahtera Abadi

\section{Populasi dan Sampel}

Penelitian ini dilakukan di kantor PT. Inti Manunggal Sejahtera Abadi. Jenis penelitian yang dilakukan adalah penelitian kuantitatif dengan kategori penelitian asosiatif kausal merupakan penelitian. Populasi dalam penelitian ini adalah seluruh karyawan produksi PT. Inti Manunggal Sejahtera Abadi sejumlah 44 karyawan. Untuk itu jumlah sampel dalam penelitian ini adalah sebanyak 44 sampel. Pengambilan sampel dalam penelitian ini menggunakan teknik sampling metode sensus, yaitu teknik penetapan jumlah sampel dengan mengikutsertakan seluruh populasi.

\section{HASIL PENELITIAN DAN PEMBAHASAN}

\section{Hasil Penelitian}

a. Uji Validitas dan Reliabilitas Data

Data yang digunakan dalam penelitian ini telah lolos uji validitas dan reliabilitas data.

b. Analisis Regresi Linier Berganda

Hasil perhitungan regresi antara variabel lingkungan kerja $\left(\mathrm{X}_{1}\right)$, beban kerja $\left(\mathrm{X}_{2}\right)$ dan konflik kerja $\left(\mathrm{X}_{3}\right)$ sebagai variabel independent terhadap stres kerja pada karyawan PT. Inti Manunggal Sejahtera Abadi sebagai variabel dependent (Y) dapat dilihat pada tabel sebagai berikut:

\section{Tabel 1}

\section{Hasil Analisis Regresi}

Coefficients $^{\mathrm{a}}$

\begin{tabular}{|c|c|c|c|c|c|c|}
\hline \multirow{2}{*}{\multicolumn{2}{|c|}{ Model }} & \multicolumn{2}{|c|}{ Unstandardized Coefficients } & \multirow{2}{*}{$\begin{array}{c}\begin{array}{l}\text { Standardized } \\
\text { Coefficients }\end{array} \\
\text { Beta }\end{array}$} & \multirow[b]{2}{*}{$\mathrm{t}$} & \multirow[b]{2}{*}{ Sig. } \\
\hline & & B & Std. Error & & & \\
\hline \multirow[t]{4}{*}{1} & (Constant) & -1.166 & 12.412 & & -.094 & .926 \\
\hline & LINGKUNGAN & -.233 & .295 & -.099 & -.790 & .434 \\
\hline & BEBAN & .806 & .199 & .516 & 4.050 & .000 \\
\hline & KONFLIK & .419 & .224 & .234 & 1.875 & .068 \\
\hline
\end{tabular}

a. Dependent Variable: STRES 
berikut:

Dari hasil uji regresi pada Tabel 1 dapat diformulasikan persamaan regresi sebagai

$$
\begin{array}{r}
Y=a+b_{1} X_{1}+b_{2} X_{2}+b_{3} X_{3}+e \\
Y=-1,166+-0,233 X_{1}+0,806 X_{2}+0,419 X_{3}
\end{array}
$$

Keterangan:

$\mathrm{Y}=$ stres kerja pada karyawan PT. Inti Manunggal Sejahtera Abadi

a $\quad=$ konstanta

$\mathrm{X}_{1} \quad=$ lingkungan kerja

$\mathrm{X}_{2} \quad=$ beban kerja

$\mathrm{X}_{3} \quad=$ konflik kerja

Dari persamaan tersebut, dapat diidentifikasikan beberapa hal sebagai berikut:

a. Nilai konstanta sebesar -1.166; menunjukkan bahwa stres kerja akan bernilai konstan sebesar -1.166 apabila variabel lingkungan kerja $\left(\mathrm{X}_{1}\right)$, beban kerja $\left(\mathrm{X}_{2}\right)$ dan konflik kerja $\left(\mathrm{X}_{3}\right)$ sama dengan nol (tidak ada) dengan asumsi faktor-faktor lain tetap atau tidak berubah nilainya.

b. Variabel lingkungan kerja $\left(\mathrm{X}_{1}\right)$ yang bernilai sebesar -0.233 (negatif) menujukkan besarnya pengaruh lingkungan kerja terhadap stres kerja pada karyawan berkorelasi negatif sehingga setiap kenaikan pada lingkungan kerja menyebabkan turunnya stres kerja pada karyawan PT. Inti Manunggal Sejahtera Abadi.

c. Variabel beban kerja $\left(\mathrm{X}_{2}\right)$ yang bernilai sebesar 0.806 (positif) menujukkan besarnya pengaruh beban kerja terhadap stres kerja pada karyawan berkorelasi positif sehingga setiap kenaikan pada beban kerja menyebabkan naiknya stres kerja pada karyawan PT. Inti Manunggal Sejahtera Abadi.

d. Variabel lingkungan kerja $\left(\mathrm{X}_{1}\right)$ yang bernilai sebesar 0.413 (postif) menujukkan besarnya pengaruh konflik kerja terhadap stres kerja pada karyawan berkorelasi positif sehingga setiap kenaikan pada lingkungan kerja menyebabkan naiknya stres kerja pada karyawan PT. Inti Manunggal Sejahtera Abadi.

e. Dilihat dari nilai pada koefisien regresi, maka dapat diketahui bahwa lingkungan kerja, beban kerja dan konflik kerja berpengaruh positif terhadap stres kerja pada karyawan PT. Inti Manunggal Sejahtera Abadi.

\section{Analisis Koefisien Determinasi (Uji R $\left.{ }^{2}\right)$}

Koefisien determinasi $\left(\mathrm{R}^{2}\right)$ digunakan untuk mengetahui seberapa besar pengeruh variabel independen secara serentak terhadap variabel dependen (Duwi Priyatno, 2014:142).

Tabel 2

\section{Hasil Koefisien Determinasi}

\begin{tabular}{|l|c|r|r|c|}
\hline Model & R & R Square & $\begin{array}{c}\text { Adjusted R } \\
\text { Square }\end{array}$ & $\begin{array}{c}\text { Std. Error of the } \\
\text { Estimate }\end{array}$ \\
\hline 1 & $.627^{\mathrm{a}}$ & .394 & .348 & 6.08262 \\
\hline
\end{tabular}

a. Predictors: (Constant), KONFLIK, LINGKUNGAN, BEBAN

b. Dependent Variable: STRES

a. Multiple Coeficient of Determination (R Square) 
Dari hasil penelitian pada Tabel 2 dapat diketahui bahwa besarnya $R$ Square adalah 0.394 atau $39.4 \%$ yang berarti bahwa persentase sumbangan pengaruh variabel independen (lingkungan kerja, beban kerja dan konflik kerja) terhadap variabel dependen (stres kerja karyawan). Sedangkan sisanya sebesar 60,6\% $(100 \%-39,4 \%=60,6 \%)$ dipengaruhi atau dijelaskan oleh variabel lain yang tidak dimasukkan dalam penelitian ini, misalnya kepemimpinan dan kompensasi.

b. Uji t

Tabel 3

Hasil Uji t

\begin{tabular}{|ll|r|r|r|r|r|}
\hline \multirow{2}{*}{ Model } & \multicolumn{2}{|c|}{$\begin{array}{c}\text { Unstandardized } \\
\text { Coefficients }\end{array}$} & $\begin{array}{c}\text { Standardized } \\
\text { Coefficients }\end{array}$ & & \\
\cline { 2 - 4 } & \multicolumn{1}{c|}{$\mathrm{B}$} & Std. Error & \multicolumn{1}{c|}{ Beta } & \multicolumn{1}{c|}{$\mathrm{t}$} & \multicolumn{1}{c|}{ Sig. } \\
\hline 1 & (Constant) & -1.166 & 12.412 & & -.094 & .926 \\
& LINGKUNGAN & -.233 & .295 & -.099 & -.790 & .434 \\
& BEBAN & .806 & .199 & .516 & 4.050 & .000 \\
& KONFLIK & .419 & .224 & .234 & 1.875 & .068 \\
\hline
\end{tabular}

Dari hasil penelitian dalam Tabel 3, pada variabel lngungan kerja diperoleh nilai $t_{\text {hitung }}$ sebesar -0.790 lebih kecil dari $t_{\text {tabel }}(1.684)$, hal ini berarti tidak ada pengaruh yang signifikan antara lingkungan kerja terhadap stres kerja karyawan. Sedangkan variabel beban kerja diperoleh nilai $t_{\text {hitung }}$ sebesar 4.050 lebih besar dari $t_{\text {tabel }}$ (1.684) dan variabel konflik kerja diperoleh nilai $t_{\text {hitung }}$ sebesar 1.875 lebih besar dari $t_{\text {tabel }}$ (1.684) maka dapat disimpulkan bahwa ada pengaruh yang signifikan antara beban kerja dan konflik kerja terhadap stres kerja karyawan PT. Inti Manunggal Sejahtera Abadi.

c. Uji F (Secara Simultan)

Melalui penghitungan data dengan menggunakan program SPSS 23.0, dapat diketahui nilai $F_{\text {hitung }}$ seperti dalam tabel sebagai berikut:

Tabel 4

ANOVA $^{\mathrm{a}}$

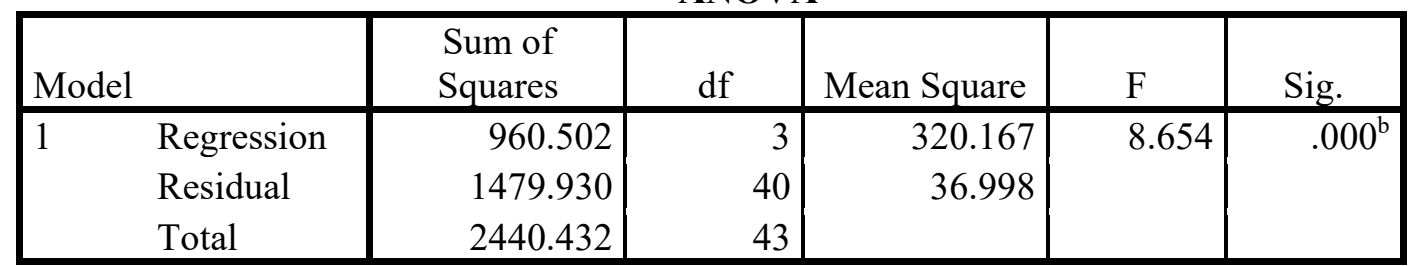

a. Dependent Variable: STRES

b. Predictors: (Constant), KONFLIK, LINGKUNGAN, BEBAN

Kriteria pengujian yang digunakan adalah dengan menentukan nilai $\mathrm{F}_{\text {tabel }}$ terlebih dahulu. Nilai $\mathrm{F}_{\text {tabel }}$ diperoleh melalui penentuan nilai level of significant $(\alpha)$ serta df. Pembilang (df1) dan df penyebut (df2). Dalam penelitian ini, dipilih level of significant $(\alpha)=0,05(5 \%)$. Jumlah sampel yang digunakan dalam penelitian adalah 44 responden dengan jumlah variabel bebas sebanyak 3 (tiga) buah, yaitu lingkungan kerja $\left(\mathrm{X}_{1}\right)$, beban kerja $\left(\mathrm{X}_{2}\right)$, dan konflik kerja $\left(\mathrm{X}_{3}\right)$. Dengan demikian diperoleh nilai df. Pembilang $(\mathrm{df} 1)=\mathrm{k}=3$ dan df penyebut $(\mathrm{df} 2)=\mathrm{n}-$ $\mathrm{k}-1=44-3-1=40$. Pada tabel $\mathrm{F}$, dengan level of significant $(\alpha)=0,05(5 \%)$ diperoleh nilai $\mathrm{F}_{\text {tabel }}=2,807$. 
Dari hasil perhitungan yang ditunjukkan oleh Tabel 4 di atas, diperoleh nilai $\mathrm{F}_{\text {hitung }}$ sebesar 8.654. Dari angka tersebut berarti $F_{\text {hitung }}$ (8.654) lebih besar daripada $F_{\text {tabel }}$ (2.807), maka Ho ditolak. Hal ini berarti terdapat pengaruh yang signifikan antara lingkungan kerja, beban kerja dan konflik kerja terhadap stres kerja karyawan PT. Inti Manunggal Sejahtera Abadi.

\section{Pembahasan}

\section{a. Pengaruh Lingkungan Kerja terhadap Stres Kerja Karyawan PT. Inti Manunggal Sejahtera Abadi}

Hasil penelitian ini menunjukkan bahwa lingkungan kerja tidak berpengaruh terhadap stres kerja karyawan PT. Inti Manunggal Sejahtera Abadi. Berdasarkan uji t diketahui bahwa nilai $t_{\text {hitung }}$ sebesar $-0,790$ (negatif) lebih kecil dari $t_{\text {tabel }}$ (1.684), maka Ho diterima dan Ha ditolak. Hal ini berarti tidak ada pengaruh yang signifikan antara lingkungan kerja dengan stres kerja karyawan. Menurut Sedarmayanti (2011:1) menyatakan bahwa lingkungan kerja merupakan keseluruhan alat perkakas dan bahan yang dihadapi, lingkungan sekitarnya dimana seseorang bekerja, metode kerjanya, serta pengaturan kerjanya baik sebagai perseorangan maupun sebagai kelompok. Kondisi lingkungan kerja dikatakan baik atau sesuai apabila manusia dapat melaksanakan kegiatan secara optimal, sehat, aman, dan nyaman.

Dalam penelitian ini lingkungan kerja tidak berpengaruh terhadap stres kerja karyawan. Hal ini mungkin bertentangan dengan pendapat yang menyatakan bahwa lingkungan kerja yang baik akan mendorong seseorang untuk bekerja lebih baik dan bersikap positif seperti mempunyai kesetiaan yang tinggi, kerjasama dan kedisiplinan dalam kewajiban. Tidak berpengaruhnya lingkungan kerja terhadap stres kerja karyawan PT. Inti Manungga Sejahtera Abadi dimungkinkan karena lingkungan kerja di perusahaan tersebut bukanlah dasar pertimbangan karyawan dalam melaksanakan tugas dan pekerjaa. Karyawan lebih mempertimbangkan beban kerja yang berlebih dan konflik yang ada dalam pekerjaan dibandingkan lingkungan kerja dalam menjalankan tugas.

\section{b. Pengaruh Beban Kerja terhadap Stres Kerja Karyawan PT. Inti Manunggal Sejahtera Abadi}

Hasil penelitian juga menunjukkan adanya pengaruh yang signifikan antara beban kerja terhadap stres kerja karyawan PT. Inti Manunggal Sejahtera Abadi. Dari uji t diperoleh besarnya nilai thitung sebesar 4.050 lebih besar dari tabel (1.684) dan nilai $p$ value sebesar 0,000 lebih kecil dari $\alpha(0,05)$. Hal ini juga diperkuat oleh Munandar (2012:383) menyatakan bahwa beban kerja merupakan suatu kondisi dari pekerjaan dengan uraian tugasnya yang harus diselesaikan pada batas waktu tertentu. Dalam penelitian ini beban kerja berpengaruh terhadap stres kerja karyawan. Karena memang waktu yang disediakan untuk menyelesaikan pekerjaan tidak cukup. Sehingga karyawan harus lembur untuk menyelesaikan pekerjaannya. Hal ini mungkin akan dianggap suatu beban oleh karyawan, sehingga menyebabkan karyawan merasa tertekan dan stres dalam menghadapi tugas dan pekerjaan.

\section{c. Pengaruh Konflik Kerja terhadap Stres Kerja Karyawan PT. Inti Manunggal Sejahtera Abadi}

Hasil penelitian juga menunjukkan adanya pengaruh positif tetapi tidak signifikan antara konflik kerja terhadap stres kerja karyawan PT. Inti Manunggal Sejahtera Abadi. Dari uji t diperoleh besarnya nilai thitung sebesar 1.875 lebih besar dari tabel (1.684) dan nilai $p$ value sebesar 0,068 lebih besar dari $\alpha(0,05)$. Hal ini juga diperkuat oleh Wahyudi (2011:17) menjelaskan bahwa konflik adalah perselisihan, pertentangan antara dua orang atau kelompok dimana perbuatan yang satu berlawanan dengan yang lainnya sehingga salah satu dan atau 
keduanya saling terganggu. Dalam penelitian ini konflik kerja berpengaruh terhadap stres kerja karyawan. Karena, adanya perbedaan persepsi antar karyawan sehingga seringkali terjadi salah faham dan mengakibatkan koordinasi kerja tidak dilakukan.

\section{d. Pengaruh Lingkungan Kerja, Beban Kerja dan Konflik Kerja terhadap Stres Kerja pada Karyawan PT. Inti Manunggal Sejahtera Abadi}

Berdasarkan hasil penelitian diketahui bahwa lingkungan kerja, beban kerja dan konflik kerja secara simultan berpengaruh terhadap stres kerja karyawan PT. Inti Manunggal Sejahtera Abadi. Hal ini dibuktikan dengan uji $\mathrm{F}$ yang diperoleh besarnya nilai $\mathrm{F}_{\text {hitung }}$ sebesar 8.654. Dari angka tersebut berarti $F_{\text {hitung }}(8.654)$.

Lingkungan kerja, beban kerja dan konflik kerja secara simultan berpengaruh terhadap stres kerja karyawan PT. Inti Manunggal Sejahtera Abadi. Jika seorang karyawan berada di lingkungan kerja yang tidak nyaman dan tidak mendukung karyawan untuk dapat menjalankan aktivitasnya dengan baik, mendapat beban kerja yang tidak sesuai dengan tugas dan kemampuannya, serta mengalami konflik dalam pekerjaan, maka karyawan tersebut akan merasa stres dan tertekan.

Lingkungan kerja yang buruk, beban kerja yang menumpuk serta konflik antar karyawan dapat menyebabkan stres kerja pada karyawan. Sebaliknya, lingkungan kerja yang kondusif, pembagian tugas yang sesuai dengan kemapuan karyawan serta hubungan yang harmonis dan dinamis di antara karyawan maupun pimpinan akan membuat karyawan merasa nyaman dan dapat bekerja dengan tenang.

\section{KESIMPULAN DAN SARAN}

\section{Kesimpulan}

Penelitian ini bertujuan untuk mengetahui pengaruh dari lingkungan kerja, beban kerja dan konflik kerja terhadap stres kerja karyawan PT. Inti Manunggal Sejahtera Abadi. Berdasarkan hasil analisis data dapat ditarik beberapa kesimpulan bahwa lingkungan kerja, beban kerja dan konflik kerja secara simultan berpengaruh terhadap stres kerja karyawan PT. Inti Manunggal Sejahtera Abadi. Dari hasil penelitian ini juga menunjukkan bahwa beban kerja dan konflik kerja merupakan faktor yang paling berpengaruh terhadap stres kerja karyawna PT. Inti Manunggal Sejahtera Abadi.

\section{Saran}

Berdasarkan hasil penelitian tersebut di atas, dalam penelitian ini dapat disampaikan saran-saran sebagai berikut:

1. Bagi Perusahaan

Untuk mengatasi tingkat stres kerja karyawan PT. Inti Manunggal Sejahtera Abadi perlu mengatur beban kerja setiap karyawan dan menambah jumlah karyawan jika memang diperlukan. Sehingga, tidak terlalu membebani karyawan. Karena beban kerja yang terlalu tinggi akan berdampak terjadinya in-efisiensi kerja.Jika terjadi kekurangan tenaga kerja atau banyaknya pekerjaan dengan jumlah karyawan yang dipekerjakan sedikit, dapat menyebabkan keletihan fisik maupun psikologis bagi karyawan. Akhirnya karyawan pun menjadi tidak produktif karena terlalu lelah. Selain itu diharapkan perusahaan selalu berusaha untuk mengendalikan konflik yang terjadi pada karyawan, yaitu dengan memberikan solusi setiap permasalahan yang terjadi pada karyawan.

2. Bagi Karyawan

Peneliti menyarankan kepada karyawan untuk berupaya mencegah stres kerja, dapat dilakukan melalui: olah raga, refreshing pribadi, meningkatkan kualitas dan kuantitas komunikasi dengan atasan.

3. Bagi Peneliti 
Peneliti selanjutnya disarankan agar menambah variabel independen, sehingga variabel stres kerja dapat dijelaskan lebih baik dan sempurna. Selain itu peneliti selanjutnya dapat memperbesar populasi penelitian agar hasil yang didapatkan lebih akurat.

\section{DAFTAR PUSTAKA}

Evanjeli, A. L. (2012). Hubungan antara stres, somatisasi dan kebahagiaan. laporan penelitian. Yogyakarta: Fakultas Psikologi Universitas Gajah Mada. pp 1-26.

Hasibuan, Malayu S. P. 2012. Manajemen Sumber Daya Manusia. Jakarta: PT. Bumi Aksara

T. Hani Handoko. 2014. Manajemen Edisi 2. Yogyakarta : BPFE Yogyakarta.

Mangkunegara, A.A. Anwar Prabu. 2011. Manajemen Sumber Daya Manusia Perusahaan. Bandung: Rosda

Munandar. 2012. Budgeting: Perencanaan Kerja, Pengkoordinasian Kerja dan Pengawasan Kerja. Edisi Kedua. Yogyakarta: BPFE Universitas Gajah Mada.

Priyatno, Duwi. 2014. SPSS 22 Pengolah Data Terpraktis. Yogyakarta.

Sedarmayanti. 2011. Manajemen Sumber Daya Manusia, Reformasi Birokrasi dan Manajemen Pegawai Negeri Sipil. Bandung: PT Refika Adiatama.

Sunyoto, Danang. 2012. Manajemen Sumber Daya Manusia. Yogyakarta: CAPS.

Tarwaka. 2011. Ergonomi Industri, Dasar-Dasar Pengetahuan dan Aplikasi Di Tempat Kerja. Surakarta: Harapan Press.

Veithzal, Rivai. (2011). Manajemen Sumber Daya Manusia Untuk Perusahaan Dari Teori Ke Praktek. Jakarta: PT. Rajagrafindo Persada.

Wahyudi. 2011. Manajemen Konflik Dalam Organisasi. Bandung: CV. Alfabeta.

Aglis Andhita Hatmawan (2015) "Pengaruh Konflik Kerja, Beban Kerja serta Lingkungan Kerja terhadap Stres Kerja Pegawai (Studi kasus di PT. PLN (Persero) Area Madiun Raya Magetan). STIE Dharma Iswara Madiun, ASSETS : Jurnal Akuntansi dan Pendidikan, Vol.4 No.1, April 2015

Danur Mega Pratiwi, Ratri Wahyuningtyas (2014), Pengaruh Konflik Kerja, Beban Kerja serta Lingkungan Kerja terhadap Stres Kerja Pegawai. (Studi kasus di PT. Krakatau Steel Tbk. Divisi CRM)) Jurnal BisnisTelekomunikasi dan Informatika, Fakultas Ekonomi dan Bisnis, Universitas Telkom 